\title{
Linking leadership styles to customer satisfaction of Palestinian insurance sector: Mediating role of employees' performance
}

\author{
Mahmoud A. Salahat*, Abdul Halim B Abdul Majid \\ School of Business Management (SBM), College of Business, Universiti Utara Malaysia, UUM 06010 Sintok, Kedah, Malaysia
}

\section{A R T I C L E IN F O}

Article history:

Received 10 September 2016

Received in revised form

25 October 2016

Accepted 11 November 2016

\section{Keywords:}

Customer satisfaction

Transactional leadership

Transformational leadership

Employees' performance

\begin{abstract}
A B S T R A C T
This study aims to examine the impact of leadership styles on customer satisfaction, in particular, transactional and transformational leadership styles. Furthermore, it examines the mediating role of employees' performance between leadership styles and customer satisfaction in the Palestinian context. Using data from a survey of 258 employees of insurance companies who have direct dealing with customers, this study tests a structural equation model that relates to leadership styles (i.e., transactional, and transformational), employees' performance and customer satisfaction. The evidence suggests that neither transactional, nor transformational leadership style impact customer satisfaction directly. On the other hand, the relationship between leadership styles and customer satisfaction is mediated partially by employees' performance.
\end{abstract}

(C) 2016 The Authors. Published by IASE. This is an open access article under the CC BY-NC-ND license (http://creativecommons.org/licenses/by-nc-nd/4.0/).

\section{Introduction}

Growing competition in the service sector has motivated the companies to invest all possible resources to improve the service quality in the eyes of customers (Salanova et al., 2005). Customer satisfaction is positively related to the market share of the company; profitability (Williams and Naumann, 2011); and financial performance (Swaminathan et al., 2014). And, the competitive strategic position of the firm (Aaker, 2008).

In spite of vital role of customer satisfaction, the current situation of customer satisfaction in the Palestinian insurance sector is not as wanted, $55 \%$ of insurance customers have changed the insurance company in 3 years or less. More than $44 \%$ of customers have the intention of switching to other insurance company. $30 \%$ of customers assure that the perceived insurance services are below their expectations.; and $30 \%$ of in customers are totally dissatisfied (Asad, 2014).

Furthermore, Palestinian insurance companies have many problems in terms of customer satisfaction, the practices adopted by these companies led to decreasing the level of their service quality (El-Jafari et al., 2003); and there is a lack of

\footnotetext{
* Corresponding Author.

Email Address: Mahmoud@paluniv.edu.ps (M. A. Salahat) https://doi.org/10.21833/ijaas.2016.11.013

2313-626X/C 2016 The Authors. Published by IASE.

This is an open access article under the CC BY-NC-ND license (http://creativecommons.org/licenses/by-nc-nd/4.0/)
}

trust between insurers and customers (Quzat, 2009). Traditionally, researchers have focused on different types of service relationships (Gutek, 1995; Gutek et al., 1999). and paid less attention to internal organizational factors contributing to service quality (Colgate and Danaher, 2000). Hence, this study aimed to investigate the relationship between internal organizational functioning and customer satisfaction. More specifically, and based on the recommendations of other scholars to conduct further researches about the role of leadership styles in customer satisfaction (Namasivayam et al., 2014; Sila and Ebrahimpour, 2005). This study focuses on the effect of transactional and transformational leadership styles on customer satisfaction through their impact on employees' performance.

\section{Literature review and hypotheses development}

\subsection{Transactional leadership style}

Transactional leadership style refers to attract followers by their own self-interests and establish an exchange relationships with them (Othman et al., 2012). A transactional leader has the ability to manage the followers' behaviors and company's resources to achieve organizational objectives (Siewiorek et al., 2013). By actualizing predetermined goals and assuring the fulfillment of the followers toward their obligations and monitoring them (Antonakis et al., 2003). 
The philosophy of transactional leadership styles is embodied through 'benefits exchange' principle. In different words, employees get rewards for doing their jobs in a good way while the organization actualizes its objectives (Chaudhry and Husnain, 2012). Transactional leader is the one who motivates employees their self-interests (Othman et al., 2012). Thus, leader and follower represent a major part of the exchange process; both of them seek to meet their benefits. Furthermore, transactional leadership style consists three part: first, contingent rewards; second, active management by exception; and third, passive management by exception (Ali et al., 2014).

Contingent rewards refer to how the leaders clarify what is required and what are the roles of employees in the company's objectives achieving process, it is also facilitating the employees' job by providing the needed materials. And the leaders provide rewards and benefits for followers' fulfillment (Antonakis et al., 2003; Bennett, 2009). Furthermore, management-by-exception (active) - it refers to the continuous focus on standards of performance by the leader to assure goals achievement. Finally, management-by-exception (passive) - according to this part of transactional leadership style, leaders take their actions at the time of mistakes only or when the employees did not follow the meet the contractual obligations (Antonakis et al., 2003; Bennett, 2009).

Theoretically, transactional leadership style and customer satisfaction can be linked through resource based view theory (RBV) (Gurbuz and Mert, 2011; Hassan et al., 2013), and the theoretical framework of leadership for quality (Sakthivel et al., 2005). This linkage takes its place because the transactional leader focuses on implementing firm's strategy and actualizing its objectives. The leader who adopts this style rewards and punishes the followers according to their performance. Thus, this leadership style has a significant contribution in to organization's performance improvement (Birasnav, 2014; Tosi, 1982).

Empirically, literature review revealed that many researchers examined the effect of the transactional leadership style on customer satisfaction (Ensley et al., 2006; Longe, 2014), and concluded that, transactional leadership style has a positively relationship with firm performance and customer satisfaction. Based on that this study hypothesizes the following:

H1: There is a significant positive relationship between transactional leadership style and customer satisfaction.

\subsection{Transformational Leadership Style}

A transformational leader refers to the leader who can extracts from the employees more than what they think they can do (Basu and Green, 1997; Obiwuru Timothy et al., 2011). A transformational leader motivates the employees to achieve results beyond their expectations (Rafferty and Griffin, 2004). This kind of leaders motivate the soul of the followers (Labby et al., 2012). Hence, transformational leaders have a critical role in affecting the organizational attitudes and company's outcomes (Kelloway and Barling, 2000; Obiwuru et al., 2011).

Transformational leadership style has five components. First, idealized influence (attributes), which means leader's charisma; she or he is very self-confident and a represents a source of power and focuses on ethics. Second, idealized influence (behavior) - this feature refers to the behaviors of the leader, which is based on clear goals and values, mission and vision. Third, inspirational motivation it can be represented by how the leader draw their future in a positive way, this can be done through motivating and clarifying the followers to make their objectives achievable (Antonakis et al., 2003; Wang et al., 2014). Transformational leaders use very simple ways in order to communicate the important values and goals, and focus on high level of employees' commitment through continuous motivations (Bass, 1985; Bennett, 2009).

Fourth, intellectual stimulation - it refers to how leaders motivate and encourage the employees to be creative, and to develop their problem solving abilities. This can be done through asking them about assumptions and cases related to the organizational objectives and think to find the solutions in a creative way (Bass, 1985; Hu et al., 2012). Fifth, individualized consideration - this characteristic refers to the ability of the leader to participate in self-actualization of the employees by making them satisfied, and providing a continuous support and needed advices (Antonakis et al., 2003; Bennett, 2009).

Transformational leadership style impacts customer satisfaction, it plays a vital role in empowering the responsive capabilities of followers and the level of service innovativeness. Service responsive capability refers to the ability of the employee to satisfy the needs of customers through an effective and quick response (Avolio and Bass, 1995; Jayachandran et al., 2004). Transformational leader performs this role through her/his unique behavioral components, inspirational motivation, idealized influence, intellectual stimulation, and individualized consideration. Thus transformational leader acts the role of coach and mentor to the employees, and the followers develop the skills and techniques that could help them in several ways such as fulfilling the customer's needs (Chang, 2011).

Besides the theoretical linkages between transformational leadership style and customer satisfaction via RBV theory (Gurbuz and Mert, 2011; Hassan et al., 2013), and the theoretical framework of leadership for quality (Sakthivel et al., 2005), many prior studies examined the relationship between transformational leadership style and customer satisfaction and conclude that transformational leadership style has a positive relationship with customer satisfaction (Avolio and Bass, 1995; Chang, 2011; Jayachandran et al., 2004). And this lead as to the following hypothesis: 
$\mathrm{H} 2$ : there is a significant positive relationship between transformational leadership style and customer satisfaction.

According to literature review, the impact of the leadership styles on customer satisfaction has a long history, and several contradictions (Ekvall and Ryhammar, 1998). Some researchers concluded that there is a positive and significant relationship between leadership style and customer satisfaction (Mohammadi, 2013). And others assured that the relationship between leadership style and customer satisfaction is positive (Hassan et al., 2014; Parzinger and Nath, 2000). While, some studies examined the impact of leadership styles on customer satisfaction by using mediators (indirectly) (Chan et al., 2012); such as salespeople's customer orientation (Stock and Hoyer, 2002); and employees' satisfaction (Namasivayam et al., 2014). Moreover, other researchers concluded that, leadership styles have no relationship with customer satisfaction (Sila and Ebrahimpour, 2005; Wilson and Collier, 2000).

Based on the above debate about the relationship between leadership styles and customer satisfaction, this paper uses employees' performance as a mediator in the relationship between leadership styles and customer satisfaction, as it has not been used in this situation according to literature review, and this represent the major contribution of the present paper. Next paragraphs shows the employees' performance

\subsection{Employees' performance}

Employees' performance performs a vital role in the success of a firm's brand. Also, it is the reason behind its failure (Wallace and De Chernatony, 2009). The reason behind this is the role of employee's' behaviors in attaining organizational objectives (Liao and Chuang, 2004; Šikýřr, 2013). Employees' performance is defined as the way that the employees behave to actualize the objectives and aims that determined by the management of the organization (Abdullah and Rashid, 2013). Service employees perform a strategic role. They translate the concept of customer orientation into facts through service providing process and service quality (Gountas et al., 2014; Hartline et al., 2000). Usually, the first contact of the customers is with the employee who is providing the service; thus, the customer's perception is created after this dealing (Hunt and Davis, 2012). Employees' performance is embodied through the interaction between the employee (service provider) and the customers of the firm. It can be seen as a mediator between the process of employment and customer satisfaction. In other words, customers have assured that employees' performance has a significant impact on customers' perceptions (Nguyen and Leclerc, 2011); and customers' evaluation of services (Zhang et al., 2011). Thus, employees' performance is a critical factor in determining the perceived value of the service (Gagić et al., 2013; Mittal and Lassar, 1996).
In the service sector, the satisfaction of customers depends on the face-to-face interaction between customers and employees (Bitner et al., 1994; Walsh et al., 2012); and as a result of the intangible and interactive nature of services, customers often rely on the behavior of service employees when judging the quality of a service (Hennig, 2004). Besides, employees' performance affects the work quality and service (Griffin et al., 2012).

Furthermore, this study uses employees' performance as a mediator between leadership styles and customer satisfaction. According to Baron and Kenny (1986), a mediator is used to explain why or how the IVs impact the DV. A variable acts as a mediator when it meets three conditions:

1.Variations in levels of the independent variable significantly account for variations in the mediator;

2. Variations in the mediator significantly account for variations in the dependent variable;

3. When conditions 1 and 2 above are controlled, a previously significant relation between the independent and dependent variables is no longer significant.

Theoretically speaking, Leadership styles and employees' performance are linked through the Path-Goal theory, and one of the most important strategic role of the leaders is to empower the psychological situation of their employees to keep them highly motivated towards their jobs (House, 1971; Stinson and Johnson, 1975). Many studies examined the impact of leadership styles on employees' performance (Abbas and Yaqoob, 2009; Purvanova et al., 2006). Leadership styles represent critical factors that affect employees' performance (Garg and Rastogi, 2006). In the same time, the third factor of the Three-Factor theory of customer satisfaction is the performance of service employees (Füller and Matzler, 2008; Matzler et al., 2003).

Along the same line, empirical studies in prior literature revealed that employees' performance is a critical factor in shaping the perceived value of the service quality and customer satisfaction (Abbasi and Alvi, 2013; Roy, 2012). In the same time, leadership styles affect employees' performance positively (Abbas and Yaqoob, 2009; Bono and Judge, 2003; Lu and Yang, 2010; Purvanova et al., 2006). This study uses extra-role and in-role performance as the dimensions of the employees' performance.

\subsubsection{In-role performance}

In-role refers to behaviors that are consistent with formal job descriptions (Varela and Landis, 2010). It is defined as the formal requirements or activities that the employee is expected to fulfill it contributes indirectly or directly to the technical core of the organization (Wu et al., 2012). So, it is a compulsory requirement for the employees to get the compensation and any other benefits from the organization (Chen et al., 2014). 
Previous studies revealed that there is a relationship between leadership styles and in-role performance, leadership styles aiming to clarify the tasks for the employees (Pieterse et al., 2010). And many researchers examined the impact of leadership styles on in-role performance and the outcomes was positive (Chen et al., 2014; Peterson et al., 2012). Similarly, The relationship between inrole performance and customer satisfaction was studied by many scholars and they conclude that inrole performance has a positive effect on customer satisfaction (Namasivayam et al., 2014; Yavas et al., 2013).

\subsubsection{Extra-role performance}

Extra-role performance refers to employees' performance that go beyond the formal task requirements (Lam et al., 2013). Also, it can be called organizational citizenship behaviors (OCB), it is defined as discretionary behaviors on the part of an employee that are thought to directly promote the effective functioning of an organization without necessarily directly influencing the productivity of the employee (Bakker et al., 2012).

According to prior literature extra-role performance affects customer satisfaction, many researchers concluded that extra-role performance has a positive relationship with customer satisfaction (Kane et al., 2012; Schaufeli, 2013). This effect could be justified because extrarole performance plays a vital role in translating the climate of service companies nto customer satisfaction and other components of organization's performance (Yavas et al., 2013). Similarly, leadership styles affect extra-role performance, several studies concluded that leadership styles have a positive relationship with extra-role performance (Biswas and Varma, 2011; Lam and O'Higgins, 2012).

Based on the previous discussion the present study hypothesizes the following:

H3: Employees' performance mediates the relationship between leadership styles and customer satisfaction.

H3a: In-role performance mediates the relationship between Leadership styles and customer satisfaction.

H3b: Extra-role performance mediates the relationship between Leadership styles and customer satisfaction.

The previous paragraphs clarified the literature review and the hypotheses of the present study. Furthermore, the proposed theoretical framework is illustrated in Fig. 1.

\section{Research methodology}

Survey questionnaire with a cover letter was personally distributed to the employees who have direct dealing with customers. We chose the these employees as a source of information for this study because they are knowledgeable about the customer satisfaction and we followed the same logic of several previous studies (Cantarello et al., 2012; Rogg et al., 2001). A total of 358 questionnaires were distributed in April to June 2015. A total of 259 questionnaires were returned. 11 of the returned questionnaire had major missing answers. Consequently, a total of 258 completed questionnaires, which represent a response rate of $75.1 \%$, were used to perform data analysis. For the purpose of testing response bias, we perform t-test for early and late response as suggested by (Armstrong and Overton, 1977). No statically significant differences were found in the mean score on the transactional leadership style, transformational leadership style, employees' performance, and customer satisfaction between the early and late respondents.

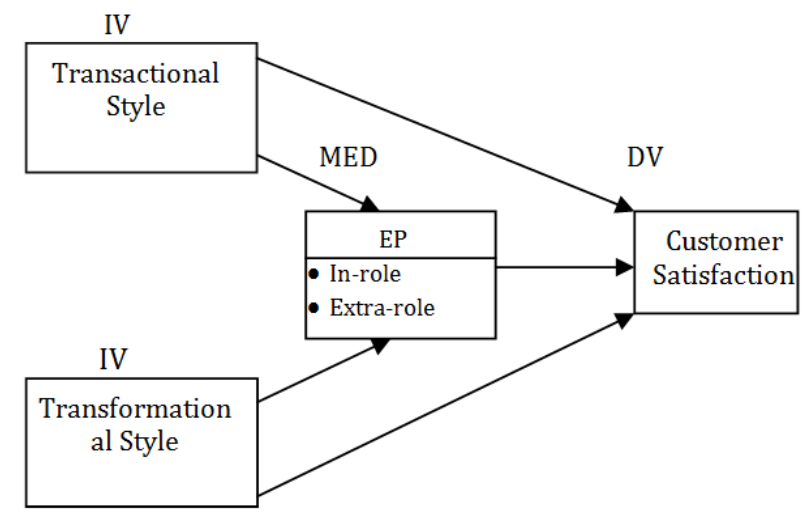

Fig. 1: Theoretical framework

\section{Variables measurements}

This study is based the framework that clarified in Fig. 1 above, customer satisfaction (DV) was measured by using the instrument of Tan and Tracey, Respondents were asked to choose their preference from a five point Likert scale ranging from 1 (strongly disagree) to 5 (strongly agree) (Tan and Tracey, 2007). Transformational and transactional leadership styles (IVs) were measured by using items adopted from Amitay and others, Respondents were asked to choose their preference from a five point Likert scale ranging from 1 (strongly disagree) to 5 (strongly agree) (Amitay et al., 2005). Similarly, employees' performance (mediator) was measured by using the items adopted from Tjosvold and Yu, Respondents were asked to choose their preference from a five point Likert scale ranging from 1 (strongly disagree) to 5 (strongly agree) (Tjosvold and Yu, 2004).

\section{Data analysis and research results}

Using SmartPLS 2, we analyzed the collected data. Table 1 provides outer convergent validity statistics for all items with respect to its variables. All factor loading of the research measurements exceed the cut-off 0.70 , which reflect the consistency between construct items (Hair et al., 2010). Similar, reliability test of this study was confirmed as all value of 
composite reliability exceed the recommended cutoff 0.70 and range between 0.930 to 0.973 as presented in Table 1 . In addition, the recommended standard value of average variance extracted (AVE) was found to be greater than 0.50 , in order to ensure that the latent variable has the ability to explain more than half of the variance of its indicator on average (Fornell and Bookstein, 1982). Latent variable correlation which examining the correlations between the measures of potentially overlapping constructs appear in Table 2. The table clearly shows that the values of all square root of AVE (Bold values) exceed the correlation with other constructs (elements in the rows and columns), which manifest the discriminant validity of this study.

Table 1: Outer model, convergent validity and composite reliability

\begin{tabular}{|c|c|c|c|c|}
\hline Construct & Items & Loading & $\mathrm{CR}$ & AVE \\
\hline \multirow{6}{*}{ CS } & Customers are satisfied with the service quality. & 0.903 & \multirow{6}{*}{0.956} & \multirow{6}{*}{0.785} \\
\hline & Customers are satisfied with service features. & 0.917 & & \\
\hline & Customers are loyal. & 0.881 & & \\
\hline & Customers refer new customers to purchase. & 0.842 & & \\
\hline & Customers feel we offer high value services. & 0.918 & & \\
\hline & Customers perceive the value of their money & 0.851 & & \\
\hline \multirow{5}{*}{ TAL } & Makes clear expectations. & 0.868 & \multirow{5}{*}{0.930} & \multirow{5}{*}{0.729} \\
\hline & Takes action before problems become chronic. & 0.879 & & \\
\hline & Tells us standards to carry out work. & 0.892 & & \\
\hline & Works out agreements with me. & 0.860 & & \\
\hline & Monitors performance and keeps track of mistakes. & 0.765 & & \\
\hline \multirow[t]{8}{*}{ TFL } & Instills pride in me. & 0.896 & 0.971 & 0.806 \\
\hline & Spends time teaching and coaching. & 0.873 & & \\
\hline & Considers moral and ethical consequences. & 0.874 & & \\
\hline & Views me as having different needs, abilities and aspirations. & 0.913 & & \\
\hline & Listens to my concerns. & 0.893 & & \\
\hline & Encourages me to perform. & 0.923 & & \\
\hline & Increases motivation. & 0.911 & & \\
\hline & Encourages me to think more creatively. & 0.901 & & \\
\hline \multirow{9}{*}{ In-role } & I achieve Job objectives & 0.887 & 0.970 & 0.786 \\
\hline & I meet criteria for performance. & 0.870 & & \\
\hline & I demonstrate expertise in all job-related tasks. & 0.910 & & \\
\hline & I fulfill all job requirements & 0.898 & & \\
\hline & I manage more responsibility than assigned. & 0.865 & & \\
\hline & I appear suitable for a higher level role. & 0.857 & & \\
\hline & I am competent in all areas of the job. & 0.904 & & \\
\hline & $\begin{array}{l}\text { I perform well and do tasks as expected. } \\
\end{array}$ & 0.901 & & \\
\hline & I plan and organizes to achieve objectives of the job and meet deadlines. & 0.883 & & \\
\hline \multirow{11}{*}{ Extra role } & I help other employees with their work when they have been absent. & 0.801 & \multirow{4}{*}{0.949} & \multirow{4}{*}{0.628} \\
\hline & I exhibit punctuality arriving at work on time. & 0.797 & & \\
\hline & I volunteer to do things not formally required by the job. & 0.803 & & \\
\hline & I take initiative to orient new employees to the department & 0.680 & & \\
\hline & I help others when their work load increases. & 0.678 & & \\
\hline & I coast toward the end of the day. & 0.772 & & \\
\hline & I give advance notice if unable to come to work. & 0.754 & & \\
\hline & I assist my supervisor to accomplish his duties. & 0.724 & & \\
\hline & I make innovative suggestions to improve the department quality. & 0.745 & & \\
\hline & I do not take extra breaks. & 0.811 & & \\
\hline & $\begin{array}{l}\text { I willingly attend functions not required by the organization, but helps } \\
\text { in its overall image. }\end{array}$ & 0.804 & & \\
\hline
\end{tabular}

Table 2: Discriminant validity- square root of AVE

\begin{tabular}{|c|c|c|c|c|c|}
\hline Constructs & CS & Extra & Tal & TFL & In-role \\
\hline CS & 0.886 & & & & \\
\hline Extra & 0.634 & 0.792 & & & \\
\hline TAL & 0.510 & 0.610 & 0.854 & & \\
\hline TFL & 0.544 & 0.556 & 0.834 & 0.898 & \\
\hline In-role & 0.588 & 0.751 & 0.556 & 0.508 & 0.786 \\
\hline
\end{tabular}

As this study assured its measurements validity and reliability, we preceded the bootstrapping approach to test research hypotheses. Path coefficient of the research hypotheses illustrated in Table 3. The first set of research hypotheses (H1-H2) predicted that, transactional and transformational leadership styles are positively associated with customer satisfaction. The coefficient on the path from each of leadership styles to customer satisfaction $(\mathrm{H} 1, \mathrm{H} 2)$ was rejected as the p-value is greater than 0.05 . in particularly, $(\mathrm{P}=0.1 .101),(\mathrm{P}=$ 0.365) respectively. This concludes that 
transactional and transformational leadership styles have no direct effect on customer satisfaction at
Palestinian insurance sector.

Table 3: Path coefficient of the research hypotheses

\begin{tabular}{|c|c|c|c|c|}
\hline Relationships & Std. Beta & Std. Error & P-value & Decision \\
\hline TAL $->$ CS & 0.097 & 0.088 & 1.101 & Rejected \\
\hline TFL $->$ CS & 0.038 & 0.103 & 0.365 & Rejected \\
\hline \multicolumn{5}{|c|}{ Significant at $\mathrm{P}^{*}<0.01$} \\
\hline
\end{tabular}

Similarly, bootstrapping was run to test the mediating role of employees' performance between leadership styles and customer satisfaction H3. The result is illustrated in Table 4 and Table 5.

Table 4: Mediating role of EP between TAL and CS

\begin{tabular}{|c|c|c|c|c|}
\hline Relationships & Std. Beta & Std. Error & P-value & Decision \\
\hline$T A L \rightarrow E P($ Path a $)$ & 0.594 & 0.065 & 0.000 & Accepted \\
\hline$E P \rightarrow C S($ Path $b)$ & 0.477 & 0.084 & 0.000 & Accepted \\
\hline$T A L \rightarrow C S\left(\right.$ Path $\left.c^{\prime}\right)$ & 0.267 & 0.081 & 0.000 & Accepted \\
\hline
\end{tabular}

Furthermore, the three conditions of mediating have been met. Thus, it can be concluded that Employees' performance mediates the relationship between transactional leadership style and customer satisfaction at $\mathrm{t}$ value $>1.96$. Consequently, the mediating role of in-role and extra role performance between transactional leadership style and customer satisfaction have been examined and the outcomes revealed that also the dimensions of employees' performance mediate the link between transactional leadership style and customer satisfaction.

Table 5: Mediating role of EP between TFL and CS

\begin{tabular}{|c|c|c|c|c|}
\hline Relationships & Std. Beta & Std. Error & P-value & Decision \\
\hline$T F L \rightarrow E P($ Path $a)$ & 0.607 & 0.062 & 0.000 & Accepted \\
\hline$E P \rightarrow C S($ Path $b)$ & 0.361 & 0.070 & 0.000 & Accepted \\
\hline$T F \rightarrow C S\left(\right.$ Path $\left.c^{\prime}\right)$ & 0.454 & 0.059 & 0.001 & Accepted \\
\hline
\end{tabular}

As shown in Table 5, employees' performance mediates the relationship between transformational leadership style and customer satisfaction at $\mathrm{t}$ value $>$ 1.96. Moreover, in-role and extra-role performance mediate the relationship between transformational leadership style and customer satisfaction. Based on that, H3 has been accepted.

\section{Discussion and conclusion}

This paper sought to examine the effect of transactional and transformational leadership styles on customer satisfaction of Palestinian insurance sector, and then to examine the mediating role of employees' performance between leadership styles and customer satisfaction. The first hypothesis of this study hypothesized that there is a significant positive relationship between transactional leadership style and customer satisfaction. The coefficient on this path was rejected at $(\mathrm{P}=0.097)$. This concludes there is no direct relationship between transactional leadership style and customer satisfaction. Moreover, the second hypothesis of this study hypothesized that there is a significant positive relationship between transformational leadership style and customer satisfaction. The coefficient on this path was rejected at $(\mathrm{P}=0.038)$. This concludes there is no direct relationship between transformational leadership style and customer satisfaction.
Along the same line, literature review revealed that very few researches tested the direct relationships between transactional and transformational leadership styles and customer satisfaction and found these relationships positive and significant. For instance, Mohammadi (2013) and Hassan et al. (2014), the earlier study examined the impact of leadership as a TQM critical factor on customer satisfaction in Iranian context and concluded that the result is positive and significant. The second study also examined the role of leadership styles as a TQM critical factor on customer satisfaction in Pakistan, and the result was positive. On the other hand, large number of previous studies concluded that the relationship between Leadership styles and customer satisfaction is indirect relationship, and tested it through other variables (Mediators). Based on that, this study considers its results as a logical finding; in other words, the main role of leadership of the company is to make decisions, support the employees and work processes with the necessary needs for achieving the best outcomes, provide the appropriate environment for working. So, behaviors and decisions of the leadership have no direct results, unless these decisions interact with other aspects in the organization, which leads to develop the level of customer satisfaction. The leaders of insurance companies in Palestine have to give more attention to the role of leadership styles and focus to use this 
tool in order to empower the level of customer satisfaction.

Determine whether Employees' Performance play a mediating role the relationship between Leadership Styles (transactional and transformational) and customer satisfaction in Palestinian insurance sector. For that, Hypothesis 3 states that 'Employees' performance mediates the relationship between leadership styles and customer satisfaction", was examined using PLS-SEM path modeling analysis. The finding shows that relationship between leadership styles and customer satisfaction is mediated partially employees' performance plays partial mediating role in the relationship between leadership styles and CS.

According to the results of this study, transactional and transformational leadership styles within insurance companies generate and develop the level of customer satisfaction. No previous studies tested the mediating role of employees' performance between leadership styles and customer satisfaction according to literature review and this is the major contribution of the present study. The findings of this study come in line with other scholars who concluded that, leadership styles have a positive impact on employees' performance. Also, employees; performance has a positive impact on customer satisfaction (Abbas and Yaqoob, 2009; Lu and Yang, 2010). Leaders play a critical role, they formulate the values of the organizational such as quality orientation; customer orientation. Thus, the functional values of the organization are affected by leaders' motivation (Auh et al., 2014). Leaders motivate their employees through their daily behaviors. They show them how to do the job (management by example). Moreover, the present study tested the mediation role of in-role performance and extra-role performance (the dimension of employees' performance) on the relationship between leadership styles and customer satisfaction ( $\mathrm{H} 3 \mathrm{a}, \mathrm{H} 3 \mathrm{~b})$. This finding was that all the conditions of mediating have been met by this relationship.

Based on that, the leaders of insurance sector in Palestine must adopt the both leadership styles, since these styles represent the good way toward developing the performance of insurance sector employees in Palestine and then achieving the targeted level of customer satisfaction.

\section{References}

Aaker DA (2008). Strategic market management. $4^{\text {th }}$ Edition, John Wiley and Sons, New York, USA.

Abbas Q and Yaqoob S (2009). Effect of leadership development on employee performance in Pakistan. Pakistan Economic and Social Review, 48(2): 269-292.

Abbasi S and Alvi K (2013). Impact of employee characteristics and their performance on customer satisfaction. Science International, 25(2), 387-394.
Abdullah I and Rashid Y (2013). Effect of personality on organizational commitment and employees' performance: Empirical evidence from banking sector of Pakistan. Middle-East Journal of Scientific Research, 17(6): 761-768.

Ali N, Jan S, Ali A, and Tariq M (2014). Transformational and transactional leadership as predictors of job satisfaction, commitment, perceived performance and turnover intention (empirical evidence from Malakand division, Pakistan). Life Science Journal, 11(5): 48-53.

Amitay M, Popper M, and Lipshitz R (2005). Leadership styles and organizational learning in community clinics. The Learning Organization, 12(1): 57-70.

Antonakis J, Avolio B J, and Sivasubramaniam N (2003). Context and leadership: An examination of the nine-factor full-range leadership theory using the multifactor leadership questionnaire. The Leadership Quarterly, 14(3): 261-295.

Armstrong JS and Overton TS (1977). Estimating nonresponse bias in mail surveys. Journal of Marketing Research, 14(3): 396-402.

Asad N (2014). An analysis and assessment of customer satisfaction with service quality in insurance industry in Palestine. M.Sc. Thesis, Birzeit University, Palestine.

Avolio BJ and Bass BM (1995). Individual consideration viewed at multiple levels of analysis: A multi-level framework for examining the diffusion of transformational leadership. The Leadership Quarterly, 6(2): 199-218.

Bakker AB, Demerouti E, and Lieke L (2012). Work engagement, performance, and active learning: The role of conscientiousness. Journal of Vocational Behavior, 80(2): 555-564.

Bass BM (1985). Leadership and performance beyond expectations. Free Press, New York, USA.

Basu R and Green SG (1997). Leader-member exchange and transformational leadership: An empirical examination of innovative behaviors in Leader-member dyads. Journal of Applied Social Psychology, 27(6): 477-499.

Bennett TM (2009). A study of the management leadership style preferred by it subordinates. Journal of Organizational Culture, Communications and Conflict, 13(2): 1-25.

Birasnav M (2014). Knowledge management and organizational performance in the service industry: The role of transformational leadership beyond the effects of transactional leadership. Journal of Business Research, 67(8): 1622-1629.

Biswas S and Varma A (2011). Antecedents of employee performance: an empirical investigation in India. Employee Relations, 34(2): 177-192. 
Bitner MJ, Booms BH, and Mohr LA (1994). Critical service encounters: The employee's viewpoint. Journal of Marketing, 58(4): 95-106.

Bono JE and Judge TA (2003). Self-concordance at work: Toward understanding the motivational effects of transformational leaders. Academy of Management Journal, 46(5): 554-571.

Cantarello S, Filippini R, and Nosella A (2012). Linking human resource management practices and customer satisfaction on product quality. The International Journal of Human Resource Management, 23(18): 3906-3924.

Chan PH, Ng PK, and Jee KS (2012). Identifying the link between leadership styles and TQM practices: A conceptual framework. In the $2^{\text {nd }}$ International Conference on Design and Concurrent Engineering, Melaka: 40-44.

Chang H (2011). Transformational leadership and customer satisfaction: The mediating role of service responsive capability and innovativeness. Ph.D Dissertation, Capella University, Minneapolis, USA.

Chaudhry AQ and Husnain J (2012). Impact of transactional and laissez faire leadership style on motivation. International Journal of Business and Social Science, 3(7): 258-264.

Chen XP, Eberly MB, Chiang TJ, Farh JL, and Cheng BS (2014). Affective trust in Chinese leaders linking paternalistic leadership to employee performance. Journal of Management, 40(3): 796819.

Colgate MR and Danaher PJ (2000). Implementing a customer relationship strategy: The asymmetric impact of poor versus excellent execution. Journal of the Academy of Marketing Science, 28(3): 375387.

Ekvall G and Ryhammar L (1998). Leadership style, social climate and organizational outcomes: A study of a Swedish university college. Creativity and Innovation Management, 7(3): 126-130.

El-Jafari M, Makhool B, Lafi D, and Atyani N (2003). Palestinian Service Sector and Its Role in Economic Development. Palestine Economic Policy Research Institute, Ramallah, Palestine.

Ensley MD, Pearce CL and Hmieleski KM (2006). The moderating effect of environmental dynamism on the relationship between entrepreneur leadership behavior and new venture performance. Journal of Business Venturing, 21(2): 243-263.

Fornell C and Bookstein FL (1982). Two structural equation models: LISREL and PLS applied to consumer exit-voice theory. Journal of Marketing Research, 19(4): 440-452.

Füller J and Matzler K (2008). Customer delight and market segmentation: An application of the three- factor theory of customer satisfaction on life style groups. Tourism Management, 29(1): 116-126.

Gagić S, Tešanović D, and Jovičić A (2013). The vital components of restaurant quality that affect guest satisfaction. Turizam, 17(4): 166-176.

Garg P and Rastogi R (2006). New model of job design: motivating employees' performance. Journal of Management Development, 25(6): 572587.

Gountas S, Gountas J, and Mavondo FT (2014). Exploring the associations between standards for service delivery (organisational culture), coworker support, self-efficacy, job satisfaction and customer orientation in the real estate industry. Australian Journal of Management, 39(1): 107126.

Griffin A, Gleason G, Preiss R, and Shevenaugh D (1995). Best practice for customer satisfaction in manufacturing firms. Sloan Management Review, 36(2): 87-98.

Gurbuz S and Mert IS (2011). Impact of the strategic human resource management on organizational performance: evidence from Turkey. The International Journal of Human Resource Management, 22(8): 1803-1822.

Gutek BA (1995). The dynamics of service: Reflections on the changing nature of customer/provider interactions. Jossey-Bass, New Jersey, USA.

Gutek BA, Bhappu AD, Liao-Troth MA, and Cherry B (1999). Distinguishing between service relationships and encounters. Journal of Applied Psychology, 84(2): 218-233.

Hair JF, Black WC, Babin BJ, and Anderson RE (2010). Multivariate data analysis: A global perspective. Upper Saddle River, Pearson Prentice Hall, NJ, USA.

Hartline MD, Maxham III JG, and McKee DO (2000). Corridors of influence in the dissemination of customer-oriented strategy to customer contact service employees. Journal of Marketing, 64(2): 35-50.

Hassan M, Hassan S, Khan MFA, and Iqbal A (2013). Impact of HR practices on employee satisfaction and employee loyalty: An empirical study of government owned public sector banks of Pakistan. Middle-East Journal of Scientific Research, 16(1): 01-08.

Hassan MU, Nawaz MS, Shaukat S, and Hassan S (2014). An empirical assessment of TQM dimensions and their relationship with firm performance: evidence from the textile sector of Pakistan. World Applied Sciences Journal, 30(6): 696-705.

Hennig T (2004). Customer orientation of service employees: Its impact on customer satisfaction, 
commitment, and retention. International Journal of Service Industry Management, 15(5): 460-478.

House RJ (1971). A path goal theory of leader effectiveness. Administrative Science Quarterly, 16(3): 321-339.

$\mathrm{Hu}$ J, Wang Z, Liden RC, and Sun J (2012). The influence of leader core self-evaluation on follower reports of transformational leadership. The Leadership Quarterly, 23(5): 860868.

Hunt SD and Davis DF (2012). Grounding supply chain management in resource-advantage theory: In defense of a resource-based view of the firm. Journal of Supply Chain Management, 48(2): 1420.

Jayachandran S, Hewett K, and Kaufman P (2004). Customer response capability in a sense-andrespond era: the role of customer knowledge process. Journal of the Academy of Marketing Science, 32(3): 219-233.

Kane RE, Magnusen MJ, and Perrewé PL (2012). Differential effects of identification on extra-role behavior. Career Development International, 17(1): 25-42.

Kelloway EK and Barling J (2000). What we have learned about developing transformational leaders. Leadership and Organization Development Journal, 21(7): 355-362.

Labby S, Lunenburg FC, and Slate JR (2012). Emotional Intelligence and Academic Success: A conceptual analysis for educational leaders. International journal of Educational Leadership Preparation, 7(1): 1-11.

Lam CS and O'Higgins ER (2012). Enhancing employee outcomes: The interrelated influences of managers' emotional intelligence and leadership style. Leadership and Organization Development Journal, 33(2): 149-174.

Lam LW, Loi R, and Leong C (2013). Reliance and disclosure: How supervisory justice affects trust in supervisor and extra-role performance. Asia Pacific Journal of Management, 30(1): 231-249.

Liao $H$ and Chuang A (2004). A multilevel investigation of factors influencing employee service performance and customer outcomes. Academy of Management journal, 47(1): 41-58.

Longe OJ (2014). Leadership style paradigm shift and organisational performance: A case of the nigerian cement industry. African Research Review, 8(4): 68-83.

Lu CS and Yang CS (2010). Safety leadership and safety behavior in container terminal operations. Safety Science, 48(2): 123-134.

Matzler K, Sauerwein E, and Heischmidt K (2003). Importance-performance analysis revisited: The role of the factor structure of customer satisfaction. The Service Industries Journal, 23(2): 112-129.

Mittal B and Lassar WM (1996). The role of personalization in service encounters. Journal of Retailing, 72(1): 95-109.

Mohammadi MR (2013). The effect of total quality management aspects on customer satisfaction and productivity in Iranian automotive industries. Journal of Social Issues and Humanities, 1(6): 73-77.

Namasivayam K, Guchait P, and Lei P (2014). The influence of leader empowering behaviors and employee psychological empowerment on customer satisfaction. International Journal of Contemporary Hospitality Management, 26(1): 69-84.

Nguyen N and Leclerc A (2011). The effect of service employees' competence on financial institutions' image: Benevolence as a moderator variable. Journal of Services Marketing, 25(5): 349-360.

Obiwuru TC, Okwu AT, Akpa VO, and Nwankwere IA (2011). Effects of leadership style on organizational performance: A survey of selected small scale enterprises in Ikosi-Ketu council development area of Lagos State, Nigeria. Australian Journal of Business and Management Research, 1(7): 100-111.

Othman J, D'silva JL, and Mohammed KA (2012). Determinants of transformational and transactional leadership styles on organizational commitment among top management of organizations in Malaysia. International Business Management, 6(4): 446-450.

Parzinger MJ and Nath R (2000). A study of the relationships between total quality management implementation factors and software quality. Total Quality Management, 11(3): 353-371.

Peterson SJ, Galvin BM and Lange D (2012). CEO servant leadership: Exploring executive characteristics and firm performance. Personnel Psychology, 65(3): 565-596.

Pieterse AN, Van Knippenberg D, Schippers M, and Stam D (2010). Transformational and transactional leadership and innovative behavior: The moderating role of psychological empowerment. Journal of Organizational Behavior, 31(4): 609-623.

Purvanova RK, Bono JE, and Dzieweczynski J (2006). Transformational leadership, job characteristics, and organizational citizenship performance. Human Performance, 19(1): 1-22.

Quzat A (2009). Analysis the factors behind the low growth of insurance sector in Palestine. M.Sc. Thesis, Isalmic University-Gaza.

Rafferty AE and Griffin MA (2004). Dimensions of transformational leadership: Conceptual and 
empirical extensions. The Leadership Quarterly, 15(3): 329-354.

Rogg KL, Schmidt DB, Shull C, and Schmitt N (2001). Human resource practices, organizational climate, and customer satisfaction. Journal of Management, 27(4): 431-449.

Roy B (2012). Assessing banking industry quality using the SERVQUAL model. International Journals of Marketing and Technology, 2(10): 7889.

Sakthivel P, Rajendran G, and Raju R (2005). TQM implementation and students' satisfaction of academic performance. The TQM Magazine, 17(6): 573-589.

Salanova M, Agut S, and Peiró JM (2005). Linking organizational resources and work engagement to employee performance and customer loyalty: the mediation of service climate. Journal of applied Psychology, 90(6): 1217-1227.

Schaufeli WB (2013). What is engagement? Employee engagement in theory and practice. $1^{\text {st }}$ Edition, Routledge, New York, USA.

Siewiorek A, Gegenfurtner A, Lainema T, Saarinen E, and Lehtinen E (2013). The effects of computersimulation game training on participants' opinions on leadership styles. British Journal of Educational Technology, 44(6): 1012-1035.

Šikýř M (2013). Best practices in human resource management: The source of excellent performance and sustained competitiveness. Central European Business Review, 2(1): 43-48.

Sila I and Ebrahimpour M (2005). Critical linkages among TQM factors and business results. International Journal of Operations and Production Management, 25(11): 1123-1155.

Stinson JE and Johnson TW (1975). The path-goal theory of leadership: A partial test and suggested refinement. Academy of Management Journal, 18(2): 242-252.

Stock RM and Hoyer WD (2002). Leadership style as driver of salespeoples' customer orientation. Journal of Market-Focused Management, 5(4): 355-376.

Swaminathan V, Groening C, Mittal V, and Thomaz F (2014). How achieving the dual goal of customer satisfaction and efficiency in mergers affects a firm's long-term financial performance. Journal of Service Research, 17(2): 182-194.

Tan CL and Tracey M (2007). Collaborative new product development environments: Implications for supply chain management. Journal of Supply Chain Management, 43(3): 2-15.
Tjosvold D and Yu ZY (2004). Goal interdependence and applying abilities for team in-role and extrarole performance in China. Group Dynamics: Theory, Research, and Practice, 8(2): 98-111.

Tosi H (1982). Toward a paradigm shift in the study of leadership. In Hunt JG, Sekaran $U$ and Schriescheim CA (Eds.), Leadership: Reyond Establishment Views, Carbondale: 222-233. Southern Illinois Uni. Press, Carbondale, USA.

Varela OE and Landis RS (2010). A general structure of job performance: Evidence from two studies. Journal of Business and Psychology, 25(4): 625638.

Wallace E and De Chernatony L (2009). Service employee performance: Its components and antecedents. Journal of Relationship Marketing, 8(2): 82-102.

Walsh G, Gouthier M, Gremler DD and Brach S (2012). What the eye does not see, the mind cannot reject: Can call center location explain differences in customer evaluations?. International Business Review, 21(5): 957-967.

Wang C, Tsai HT, and Tsai MT (2014). Linking transformational leadership and employee creativity in the hospitality industry: The influences of creative role identity, creative selfefficacy, and job complexity. Tourism Management, 40(2): 79-89.

Williams P and Naumann E (2011). Customer satisfaction and business performance: a firmlevel analysis. Journal of Services Marketing, 25(1): 20-32.

Wilson DD and Collier DA (2000). An empirical investigation of the Malcolm Baldrige National Quality Award causal model. Decision Sciences, 31(2): 361-383.

Wu M, Huang X, and Chan SC (2012). The influencing mechanisms of paternalistic leadership in Mainland China. Asia Pacific Business Review, 18(4): 631-648.

Yavas U, Babakus E, and Karatepe OM (2013). Does hope moderate the impact of job burnout on frontline bank employees' in-role and extra-role performances?. International Journal of Bank Marketing, 31(1): 56-70.

Zhang RY, Liu XM, Wang HZ, and Shen L (2011). Service climate and employee service performance: exploring the moderating role of job stress and organizational identification. The Service Industries Journal, 31(14): 2355-2372. 